\title{
PENGGUNAAN CETYLPERIDINIUM CHLORIDE SEBAGAI ANTI BAKTERI PADA UDANG
}

\section{Application of Cetylperidinium Chloride (CPC) as Anti Bacterial Agent on Shrimp}

\author{
Radestya Triwibowo ${ }^{1^{*}}$, Novalia Rachmawati ${ }^{1}$, dan Irma Hermana ${ }^{1}$ \\ ${ }^{1}$ Balai Besar Penelitian dan Pengembangan Pengolahan Produk dan Bioteknologi Kelautan dan Perikanan, KKP. \\ Jl. K.S. Tubun Petamburan VI, Jakarta Pusat 10260 \\ * Korespondensi Penulis: radest_fish@yahoo.com
}

Diterima: 18 Juni 2013; Disetujui: 7 November 2013

\begin{abstract}
ABSTRAK
Aplikasi Cetylperidinium Chloride (CPC) telah dilakukan pada produk udang segar yang diberi kontaminasi buatan bakteri patogen. Penggunaan CPC pada produk makanan telah mendapat persetujuan dari Food and Drug Administration (FDA) dan European Food Safety Authority (EFSA) yang dikategorikan sebagai senyawa Generally Recognized As Safe (GRAS). Bakteri patogen yang digunakan dalam penelitian ini adalah E. coli, Salmonella sp., dan Vibrio parahaemolyticus dengan kepadatan sel 0,5 McFarland. Perlakuan konsentrasi CPC yang digunakan didasarkan atas hasil penelitian pendahuluan, yaitu: 0,$4 ; 0,8$; dan $1,2 \%(\mathrm{~b} / \mathrm{v})$ dan larutan akuades digunakan sebagai kontrol. Aplikasi larutan CPC dilakukan dengan cara pencelupan udang ke dalam larutan CPC selama \pm 1 menit kemudian dikeringanginkan selama 10 menit dan dikemas. Udang disimpan pada suhu $\pm 4{ }^{\circ} \mathrm{C}$ dan $\pm 25^{\circ} \mathrm{C}$ dan dilakukan pengamatan terhadap pertumbuhan bakteri patogen. Hasil penelitian menunjukkan larutan CPC mampu menghambat pertumbuhan $E$. coli dan $V$. parahaemolyticus pada udang yang disimpan pada suhu $\pm 4{ }^{\circ} \mathrm{C}$ dan $\pm 25^{\circ} \mathrm{C}$, sedangkan pertumbuhan Salmonella sp. dapat dihambat hanya pada udang yang disimpan pada suhu $\pm 4^{\circ} \mathrm{C}$. Konsentrasi larutan CPC yang dianjurkan untuk digunakan sebagai larutan anti mikroba adalah $0,8 \%$.
\end{abstract}

KATAKUNCl: cetylperidinium chloride, udang, bakteri patogen

\section{ABSTRACT}

Application of Cetylperidinium Chloride (CPC) as anti bacterial agent has been done on artificially contaminated shrimp. Cetylperidinium Chloride application in food products has been permitted by The Food and Drug Administration (FDA) and European Food Safety Authority (EFSA) since it has been categorized as a Generally Recognized As Safe (GRAS) substance. Pathogenic bacteria used were E. coli, Salmonella sp. and Vibrio parahaemolyticus with cell density of 0.5 McFarland. Concentrations of CPC solution were based on a preliminary experiment, i.e. 0.4; 0.8; $1.2 \%(\mathrm{~W} / \mathrm{V})$ and aquadest was used as control. Shrimp was dipped into the solution for approximately 1 minute, dried for 10 minutes and packed. Shrimp was then stored at $\pm 4{ }^{\circ} \mathrm{C}$ and $\pm 25{ }^{\circ} \mathrm{C}$. The growth of pathogenic bacteria was analyzed periodically. The result showed that CPC was able to prevent the growth of E. coli and Vibrio parahaemolyticus on shrimp stored at $\pm 4{ }^{\circ} \mathrm{C}$ and $\pm 25^{\circ} \mathrm{C}$. However, the growth of Salmonella sp. was prevented on shrimp stored at $\pm 4^{\circ} \mathrm{C}$ only. Cetylperidinium Chloride at the concentration of 0.8 and $1.2 \%$ had the same effectivity, therefore the recommended concentration of CPC is $0.8 \%$.

KEYWORDS: $\quad$ cetylperidinium chloride, shrimp, pathogenic bacteria

\section{PENDAHULUAN}

Udang merupakan salah satu komoditas unggulan ekspor Indonesia ke berbagai negara, khususnya Uni Eropa, Amerika Serikat, dan Jepang. Sementara itu, kebijakan mengenai standar keamanan pangan di negara-negara tersebut meningkat sejalan dengan nilai impor udang beku yang diakibatkan oleh semakin meningkatnya kepedulian dan pengetahuan konsumen di negara tujuan mengenai jaminan keamanan pangan. Hal ini menyebabkan terjadinya beberapa kasus penolakan produk udang segar dari 
negara tujuan karena tidak memenuhi standar dan kualifikasi yang ditetapkan.

Penolakan produk udang segar yang diekspor ke negara tujuan umumnya disebabkan oleh kontaminasi bakteri patogen dan bahan-bahan berbahaya seperti histamin dan logam berat. Beberapa jenis bakteri patogen yang sering ditemukan pada produk udang yang ditolak oleh negara tujuan ekspor adalah $V$. parahaemolyticus, E. coli, dan Salmonella sp.

Berdasarkan data dari FDA pada tahun 2013, terjadi 281 kasus penolakan produk ekspor dari Indonesia (import refusal). Sebanyak 64,1\% (180 kasus) merupakan produk perikanan dan 35,9\% (108 kasus) merupakan produk non perikanan. Lebih kurang sebanyak 50\% kasus penolakan produk perikanan di pasar USA disebabkan oleh kontaminasi bakteri patogen seperti Salmonella sp. dan Listeria monocytogenes (US FDA, 2013). Berdasarkan data dari United Nations Industrial Development Organization (UNIDO), dalam rentang waktu tahun 2002 - 2010 rata-rata penolakan ekspor produk perikanan Indonesia ke Jepang, Eropa, dan Australia berturut-turut sebesar 38, 40, dan 59 kasus. Penyebab dari penolakan tersebut didominasi oleh kontaminasi bakteri (IDE-JETRO, 2013).

Beberapa upaya pencegahan yang dapat dilakukan yaitu penerapan Good Handling Practice (GHP), Good Manufacturing Practice (GMP), Standar Sanitation Operational Procedure (SSOP), dan pelaksanaan Hazard Analysis and Critical Control Point (HACCP). Di samping itu, penggunaan bahan pengawet dan zat anti bakteri yang aman juga dapat digunakan sebagai upaya mengurangi kontaminasi bakteri patogen, salah satunya adalah Cetylpyridinium Chloride (CPC).

Cetylperidinium Chloride merupakan surfaktan yang bersifat garam dengan cetyl-peridinium sebagai gugus kationik dan chlorida sebagai gugus anion yang umum digunakan sebagai antiseptik dan disinfektan (McDonnell \& Russell, 1999). Cetylperidinium Chloride yang lebih dikenal dengan nama cecure terbukti efektif membunuh bakteri patogen pada manusia, seperti Listeria monocytogenes, E. coli, Salmonella, dan Campylobacter dengan mereduksi pertumbuhan bakteri sebesar 3-6 log cfu/ml (University of Arkansas for Medical Science, 2004).

Secara umum CPC banyak digunakan sebagai larutan pencelup, penyemprot dan pencuci makanan. Dengan metode yang benar, penggunaan CPC tidak mempengaruhi tekstur, bau dan citarasa produk (Safe Foods Corporation, 2003). Cetylperidinium Chloride merupakan salah satu senyawa non-reaktif yang seringkali digunakan pada produk pasta gigi atau cairan pencuci mulut. Efektifitas CPC untuk mengurangi dan menghambat pertumbuhan bakteribakteri patogen telah banyak dipelajari. Senyawa ini mampu menghambat pertumbuhan L. monocytogenes pada produk-produk sayuran (Wang \& Johnson, 1997; Wang \& Slavik, 2001), E. coli, L. monocytogenes, S. aureus, dan $S$. thyphimurium pada daging sapi (Pohlman, 1999; Cutter, et al., 2000; Stopforth et al., 2002; Bosilevac et al. , 2004; Lim \& Mustapha, 2004; Lim \& Mustapha, 2007), serta Salmonella sp. pada produk unggas (Kim \& Slavik, 1996; Breen, et al., 1997).

Penggunaan CPC sebagai bahan tambahan pangan, terutama untuk mencegah kontaminasi bakteri patogen pada industri pengolahan unggas telah disetujui oleh FDA pada tahun 2004 (Donabeth et al., 2013) dan Komisi Uni Eropa pada tahun 2012 dengan konsentrasi 0,8 sampai 1,0\% (EFSA, 2012). Beberapa negara telah banyak menggunakan CPC sebagai bahan antibakteri pada produk sayuran dan daging dalam bentuk larutan, penggunaannya dianjurkan pada konsentrasi 0,8-1,0 \% (US FDA, 2007).

Di Indonesia, penggunaan senyawa CPC sebagai bahan antibakteri untuk produk pangan belum terdaftar di Badan Pengawasan Obat dan Makanan Republik Indonesia. Di lain pihak, informasi tentang efektifitas penggunaan CPC sebagai senyawa antibakteri pada produk perikanan masih sangat terbatas. Hal tersebut mendasari dilakukannya penelitian penggunaan CPC sebagai senyawa antibakteri pada produk udang segar. Dari penelitian ini diharapkan dapat diperoleh informasi tentang efektifitas CPC sebagai antibakteri pada produk udang segar yang dapat diterapkan di skala industri (unit pengolah ikan) pengolah udang sekaligus sebagai bahan rekomendasi senyawa alternatif pengganti klorin pada produk udang.

\section{BAHAN DAN METODE}

\section{Bahan}

Udang yang digunakan adalah udang putih (Litopennaeus vannamei) yang diperoleh dari supermarket (fresh market) dalam keadaan segar dengan ukuran 70 ekor/kg. Udang dikupas dan dibekukan dalam bentuk blok dengan berat total \pm 2,5 kg/blok, kemudian sebagian dianalisis Angka Lempeng Totalnya (ALT) (BSN, 2006). Udang dalam blok disterilisasi menggunakan metode iradiasi dengan dosis 20 kGrey di Laboratorium Isotop, Badan Tenaga Atom Nasional (BATAN). Sebelum digunakan, udang dilelehkan terlebih dahulu pada suhu ruang dalam kondisi steril dan dianalisis kembali nilai ALT-nya untuk memastikan sterilitas udang. 
Uji antibakteri larutan CPC dilakukan terhadap bakteri indikator V. parahaemolyticus ATCC 17802 , Salmonella sp ATCC 14028, dan E. coli ATCC 25922 yang diperoleh dari Remel®. Perhitungan jumlah bakteri yang tumbuh dilakukan menggunakan media agar selektif, yaitu Thiosulfate Citrate Bilesalt Sucrose (TCBS) untuk perhitungan total V. parahaemolyticus, Xylose Lysine Deoxycholate agar (XLD) untuk perhitungan total Salmonella sp. serta Eosin Methylene Blue (EMB) untuk perhitungan total E. coli.

Cetylpyridinium Chloride (Sigma) dalam bentuk padatan (kemurnian 98\%) dilarutkan menggunakan akuades steril dengan konsentrasi 0,$1 ; 0,2 ; 0,4 ; 0,8$; 1,$0 ; 1,2 ;$ dan $1,6 \%(b / v)$.

\section{Metode}

\section{Uji antibakteri larutan CPC dengan metode cakram difusi}

Penentuan konsentrasi CPC yang akan digunakan sebagai larutan pencelup udang dilakukan melalui uji antibakteri dengan metode cakram difusi. Larutan CPC dengan konsentrasi 0,$1 ; 0,2 ; 0,4 ; 0,8$; dan $1,6 \%$ diujikan terhadap bakteri indikator, sebagai kontrol digunakan Oxytetracycline $30 \mu \mathrm{g}$ (dalam bentuk cakram). Sebanyak 0,1 ml dari masing-masing konsentrasi larutan CPC diteteskan di atas cakram steril (blank disk) kemudian dikeringanginkan di dalam laminar biosafety.

Bakteri indikator Salmonella sp. dan E. coli ditumbuhkan dalam media Trypton Soya Broth (TSB) sedangkan $V$. parahaemolyticus ditumbuhkan dalam $\mathrm{TSB}+3 \% \mathrm{NaCl}$ selama \pm 24 jam. Kultur diencerkan dengan Brain Heart Infussion (BHI) hingga kepadatan sel mencapai 0,5 Mc Farland (setara dengan 1,5 $\mathrm{x}$ $10^{8} \mathrm{cfu} / \mathrm{ml}$ ). Sebanyak $50 \mu \mathrm{l} \mathrm{kultur}$ bakteri ditambahkan ke dalam media Muller Hinton Agar (MHA) dan dituang pada petridish hingga menjendal.

Cakram yang telah ditetesi dengan berbagai konsentrasi CPC dan kontrol diletakkan di atas media MHA padat, kemudian diinkubasi pada suhu $\pm 35^{\circ} \mathrm{C}$ selama 18-24 jam. Diameter zona bening $(\mathrm{mm})$ yang terbentuk di sekitar cakram diukur dan disajikan sebagai besaran zona hambat CPC. Konsentrasi larutan CPC yang memberikan zona hambat terbesar dipilih dan digunakan dalam penelitian utama.

\section{Aplikasi CPC pada udang}

Larutan CPC digunakan sebagai larutan perendam pada tahapan pencucian udang. Untuk mengetahui aktivitas antibakteri CPC, udang yang digunakan terlebih dahulu diberi perlakuan kontaminasi buatan dengan bakteri indikator. Pertumbuhan bakteri diamati setiap 6 jam untuk produk yang disimpan pada suhu kamar $\left( \pm 25^{\circ} \mathrm{C}\right)$ dan setiap 3 hari untuk produk yang disimpan pada suhu dingin $\left( \pm 4^{\circ} \mathrm{C}\right)$.

Udang yang telah disterilisasi diberi kontaminasi buatan dengan bakteri $V$. parahaemolyticus, Salmonella sp. dan E. coli. Sebanyak 150 gr udang dicelupkan ke dalam $500 \mathrm{ml}$ kultur bakteri yang telah ditumbuhkan selama 24 jam dengan kepadatan 1,5 $\mathrm{x}$ $10^{8} \mathrm{cfu} / \mathrm{ml}$ (Wanger, 2007). Pencelupan dilakukan selama \pm 1 menit, kemudian udang dikeringanginkan dalam laminar biosafety selama \pm 1 jam. Selanjutnya udang dicelupkan ke dalam larutan CPC selama \pm 1 menit dan dikeringanginkan selama \pm 10 menit. Sebagai kontrol, digunakan akuades sebagai larutan pencelup. Setelah itu udang dikemas dalam pengemas steril dan disimpan pada suhu $\pm 4^{\circ} \mathrm{C}$ dan $\pm 25^{\circ} \mathrm{C}$. Perhitungan jumlah total bakteri dilakukan menggunakan media agar selektif. Udang yang disimpan pada suhu $\pm 4^{\circ} \mathrm{C}$ diamati setiap 3 hari selama 9 hari, sedangkan udang yang disimpan pada suhu $\pm 25^{\circ} \mathrm{C}$ diamati setiap 6 jam selama 24 jam.

Percobaan disusun menggunakan Rancangan Acak Lengkap dengan perlakuan konsentrasi CPC dan dilakukan sampling sebanyak 3 kali ulangan. Hasil pengamatan ALT bakteri patogen dianalisis menggunakan Analisis Sidik Ragam, sedangkan untuk mengetahui perbedaan antar perlakuan dianalisis dengan Uji Jarak Duncan (Steel \& Torrie, 1980).

\section{HASIL DAN BAHASAN}

\section{Uji Antibakteri Larutan CPC}

Diameter zona hambat yang terbentuk dari masingmasing bakteri indikator disajikan pada Tabel 1. Oxytetracycline digunakan sebagai kontrol positif dikarenakan senyawa ini memiliki spektrum penghambatan yang luas terhadap jenis bakteri Gram positif maupun negatif (Chopra \& Roberts, 2001). Dengan terbentuknya zona hambat dari masingmasing bakteri menunjukkan bahwa jenis bakteri yang digunakan dalam penelitian ini tidak bersifat resisten terhadap zat antibakteri.

Hasil pengukuran zona hambat menunjukkan bahwa CPC pada konsentrasi $0,2-1,6 \%$ memiliki aktivitas penghambatan terhadap bakteri $V$. parahaemolyticus, Salmonella sp. dan E. coli meskipun tergolong dalam kategori lemah hingga sedang. Hal ini sesuai dengan hasil pengkategorian aktivitas penghambatan senyawa oleh Morales, et al., (2003) yaitu aktivitas lemah ( $<5 \mathrm{~mm})$, sedang (5-10 $\mathrm{mm}$ ), kuat (10-20 mm) dan sangat kuat (20-30 mm). Berdasarkan hasil tersebut, konsentrasi CPC yang digunakan untuk aplikasi sebagai larutan pencelup udang adalah 0,$4 ; 0,8$; dan $1,2 \%$. Penggunaan 
Tabel 1. Zona hambat bakteri indikator

Table 1. Inhibition zone of indicator bacteria

\begin{tabular}{|c|c|c|c|c|}
\hline \multirow{2}{*}{\multicolumn{2}{|c|}{$\begin{array}{l}\text { Perlakuan/ } \\
\text { Treatments }\end{array}$}} & \multicolumn{3}{|c|}{ Zona Hambat/Inhibition Zone $(\mathrm{mm})$} \\
\hline & & V. parahaemolyticus & Salmonella sp. & E. coli \\
\hline Oxyte & etracycline $30 \mathrm{~g}$ & 19.00 & 12.00 & 12.50 \\
\hline $\mathrm{CPCO}$ & & 1.00 & 1.00 & 1.00 \\
\hline $\mathrm{CPCO}$ & $0.1 \%$ & 1.00 & 1.00 & 1.00 \\
\hline CPC 0 & $0.2 \%$ & 3.50 & 1.00 & 2.00 \\
\hline CPC 0 & $0.4 \%$ & 4.00 & 1.50 & 2.00 \\
\hline CPC 0 & $0.8 \%$ & 5.50 & 2.00 & 3.50 \\
\hline CPC 1 & $1.6 \%$ & 8.00 & 4.00 & 6.50 \\
\hline
\end{tabular}

konsentrasi CPC yang lebih tinggi dilakukan untuk melihat kecenderungan aktifitas antibakteri CPC pada produk udang.

Cetylperidinium Chloride tergolong dalam senyawa amonium kuartener yang reaktif terhadap gugus kationik pada permukaan membran sel dimana bakteri Gram positif lebih sensitif terhadap senyawa amonium kuartener jika dibandingkan bakteri Gram negatif. Berbeda dengan bakteri Gram positif, bakteri Gram negatif memiliki membran luar yang menyebabkan sel bakteri tidak mudah ditembus oleh senyawa amonium kuartener. Pada bakteri Gram positif, senyawa amonium kuartener akan berikatan dengan fosfolipid dan protein pada membran sel, sehingga dapat

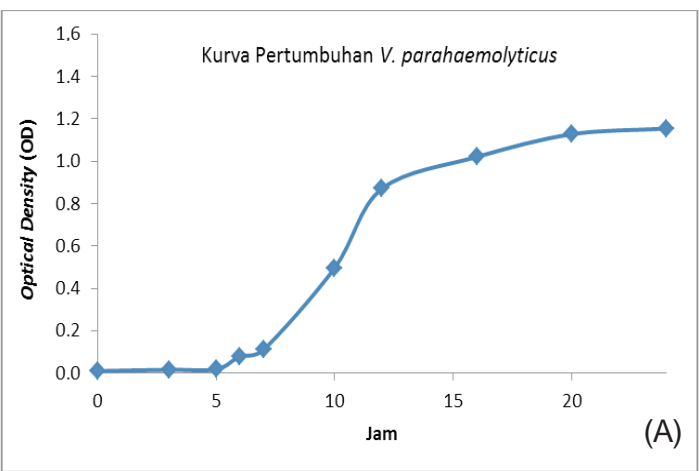

menyebabkan kerusakan pada membran sel bakteri (Maris, 1995; Tischer et al., 2012). Hal ini menyebabkan rendahnya aktifitas penghambatan CPC terhadap ketiga bakteri indikator (V. parahaemolyticus, Salmonella sp., dan E. coli) yang tergolong bakteri Gram negatif. Penggunaan CPC sebagai anti bakteri pada jenis bakteri Gram positif telah banyak dilakukan (Ozdemir, 2013), di antaranya untuk produk daging (Lim \& Mustapha, 2007) dan udang (Dupard, 2005).

Pengamatan terhadap kurva pertumbuhan masingmasing bakteri indikator yang ditumbuhkan pada suhu kamar $\left( \pm 25^{\circ} \mathrm{C}\right)$ dilakukan untuk menentukan interval waktu pengamatan pada analisis pertumbuhan bakteri indikator pada udang segar yang diberi perlakuan CPC.

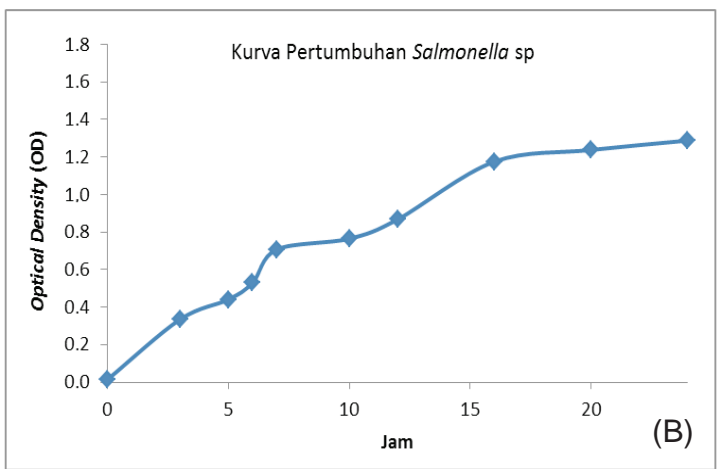

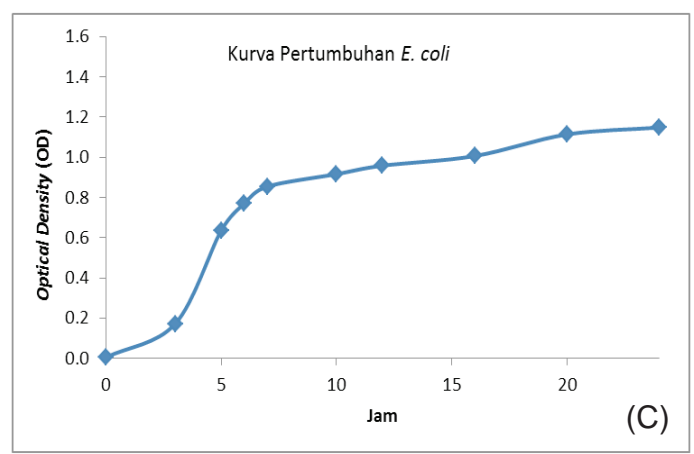

Gambar 1. Kurva pertumbuhan (A) V. parahaemolyticus; (B) Salmonella sp. dan (C) E. coli. Figure 1. Growth curve of (A) V. parahaemolyticus; (B) Salmonella sp. and (C) E. coli. 
Gambar 1 menunjukkan kurva pertumbuhan bakteri V. parahaemolyticus, Salmonella sp., dan E. coli pada suhu kamar memiliki kecenderungan yang hampir sama. Bakteri mengalami fase eksponensial sejak jam ke-6 hingga jam ke-20. Dalam rentang waktu tersebut, bakteri mencapai jumlah maksimum sehingga mudah untuk diamati. Oleh karena itu, pengamatan dilakukan setiap 6 jam sekali. Pengamatan berlangsung selama 24 jam untuk memastikan pada akhir pengamatan bakteri telah berada pada fase stasioner.

\section{Aplikasi Larutan CPC pada Udang}

Proses sterilisasi dengan metode iradiasi pada udang terbukti efektif untuk menghilangkan jumlah total bakteri alami pada udang. Sebelum diiradiasi nilai rata-rata ALT udang kurang dari 5 log cfu/gram, sedangkan setelah proses iradiasi nilai ALTnya sebesar 0 log cfu/g (steril).

\section{Pertumbuhan Bakteri pada Udang yang Disimpan pada Suhu Kamar $\left(25^{\circ} \mathrm{C}\right)$}

Kurva pertumbuhan bakteri pada udang yang disimpan pada suhu kamar disajikan pada Gambar

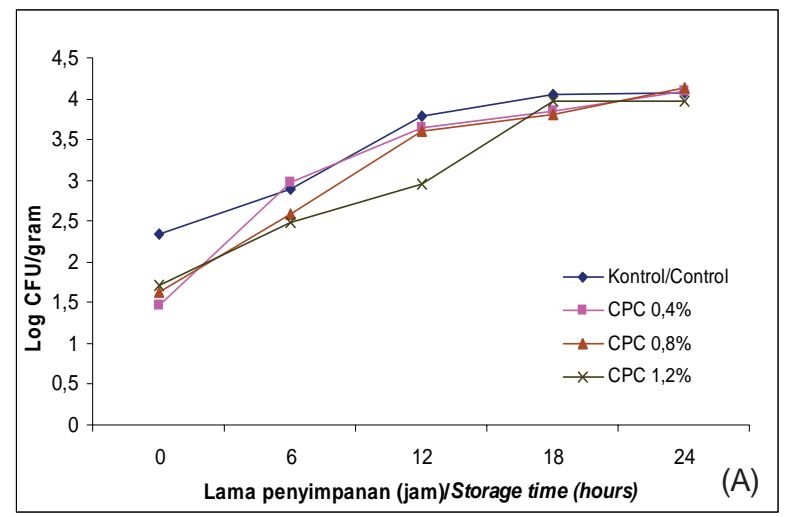

2. Pengamatan terhadap pertumbuhan bakteri pada udang yang disimpan pada suhu kamar dilakukan setiap 6 jam sekali selama 24 jam. Jumlah rata-rata bakteri Salmonella, E. coli, dan V. parahaemolyticus setelah dilakukan pencelupan dalam larutan CPC berturut-turut sebesar 5,3; 5,1; dan 1,6 log cfu/g.

Larutan CPC 1,2\% mampu menurunkan jumlah bakteri $V$. parahaemolyticus sebesar 0,63 log cfu/g dibandingkan dengan kontrol pada jam ke-0 (Gambar $2 a)$ dan berbeda nyata $(p<0,05)$, namun tidak berbeda nyata bila dibandingkan dengan perlakuan konsentrasi 0,4 dan $0,8 \%$. Hal ini sesuai dengan hasil uji antibakteri, yang menunjukkan adanya ukuran zona hambat yang lebih besar pada media MHA dengan indikator V. parahaemolyticus dibandingkan E. coli dan Salmonella sp. Namun demikian, pada titik pertama pengamatan (jam ke-3) udang yang terkontaminasi $V$. parahaemolyticus mengalami penurunan jumlah bakteri lebih rendah dibandingkan udang yang terkontaminasi $E$. coli setelah diberi perlakuan pencelupan CPC sebesar 0,1-0,5 log cfu/ g. Hal ini kemungkinan disebabkan oleh kemampuan V. parahaemolyticus untuk beradaptasi dengan matrik bahan baku udang karena bakteri ini secara alami

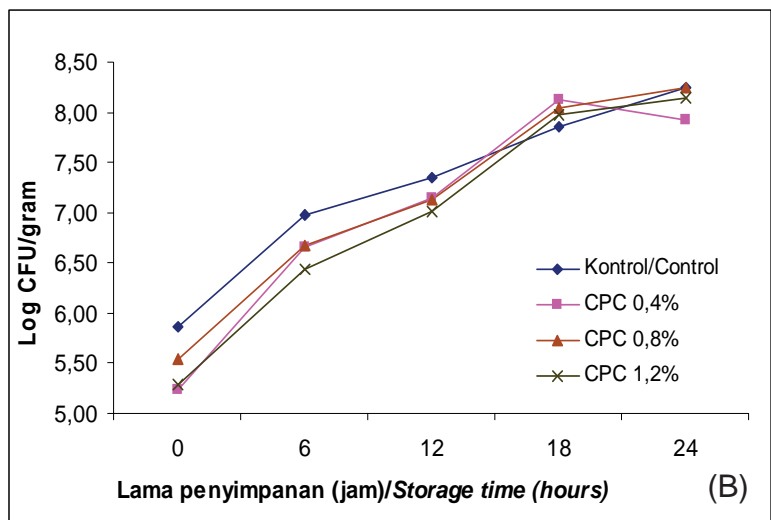

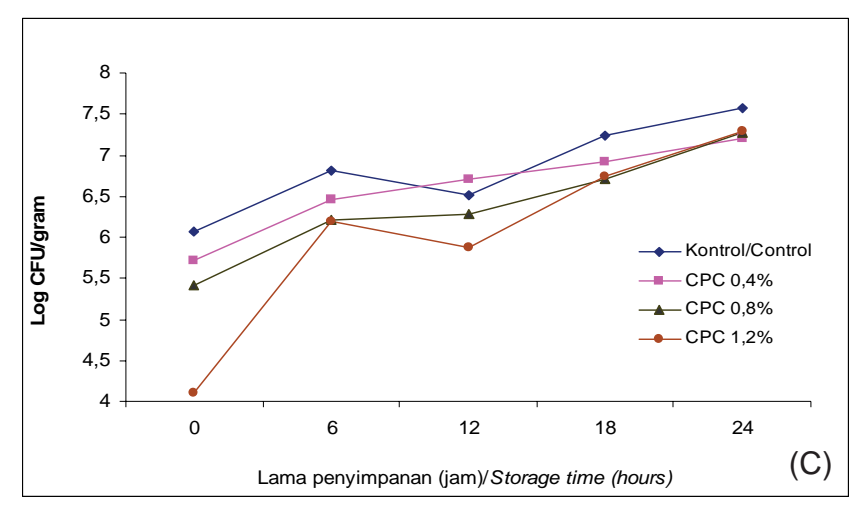

Gambar 2. Kurva pertumbuhan (A) V. parahaemolyticus (B) Salmonella sp. dan (C) E. coli, pada udang yang disimpan di suhu ruang selama 24 jam.

Figure 2. Growth curve of (A) V. parahaemolyticus (B) Salmonella sp. and (C) E. coli, in shrimp stored at ambient temperature for 24 hours. 
ditemukan pada udang yang hidup di perairan payau atau asin.

Pencelupan larutan CPC 1,2\% pada udang dapat menurunkan jumlah $E$. coli sebesar 1,96 log cfu/g pada jam ke-0 yang berbeda sangat nyata $(p<0,01)$ dibandingkan perlakuan kontrol. Sedangkan hasil analisis pada pengamatan selanjutnya $(6,12,18$, dan 24 jam), perlakuan dengan konsentrasi tertinggi (CPC $1,2 \%$ ) hanya sedikit menurunkan pertumbuhan $E$. coli dan berbeda nyata $(p<0,05)$ dibandingkan dengan kontrol dan perlakuan 0,4\%. Namun demikian penggunaan konsentrasi $1,2 \%$ tidak berbeda nyata dibandingkan dengan perlakuan $0,8 \%$. Hal ini menunjukkan bahwa perlakuan pencelupan CPC konsentrasi 0,8\% memiliki kemampuan yang sama dengan perlakuan konsentrasi $1,2 \%$ dalam menghambat pertumbuhan bakteri E. coli pada udang segar.

Pencelupan udang segar dalam larutan CPC 1,2\% juga dapat menurunkan jumlah Salmonella sp. sebesar 0,57 log cfu/g pada jam ke-0. Penurunan ini lebih kecil jika dibandingkan dengan penurunan pada E. coli, hal ini sejalan dengan hasil pengukuran zona hambat larutan CPC terhadap Salmonella sp. yang juga lebih kecil dibandingkan dengan zona hambat
E.coli (Tabel 1). Hasil analisis statistik menunjukkan bahwa perlakuan pencelupan CPC 0,$4 ; 0,8$; dan $1,2 \%$ sampai dengan jam ke-12 memberikan efek penghambatan yang tidak berbeda nyata namun bila dibandingkan perlakuan tanpa pencelupan CPC berbeda nyata $(p<0,05)$.

Batas maksimum cemaran mikrobiologi dalam produk perikanan berbeda untuk setiap negara tujuan ekspor. Untuk produk perikanan, Uni Eropa dan AS mensyaratkan tidak ditemukan Salmonella dalam 25 g sampel sebanyak 5 kali pengambilan. FDA mensyaratkan level maksimal $V$. parahaemolyticus sebesar 1 × $10^{4} \mathrm{cfu} / \mathrm{g}$ (Regulation EC 2073, 2005; US FDA, 2011). Di samping itu, negara-negara tujuan ekspor tersebut menerapkan sertifikasi HACCP, GMP, dan GHP yang ketat untuk perusahaan yang akan memasarkan produknya.

\section{Pertumbuhan Bakteri pada Udang yang Disimpan pada Suhu Dingin $\left( \pm 4^{\circ} \mathrm{C}\right)$}

Pengamatan terhadap pertumbuhan bakteri pada suhu dingin $\left( \pm 4^{\circ} \mathrm{C}\right)$ dilakukan selama 9 hari. Kurva pertumbuhan $V$. parahaemolyticus, Salmonella sp. dan E. coli pada udang yang disimpan pada suhu dingin disajikan pada Gambar 3.
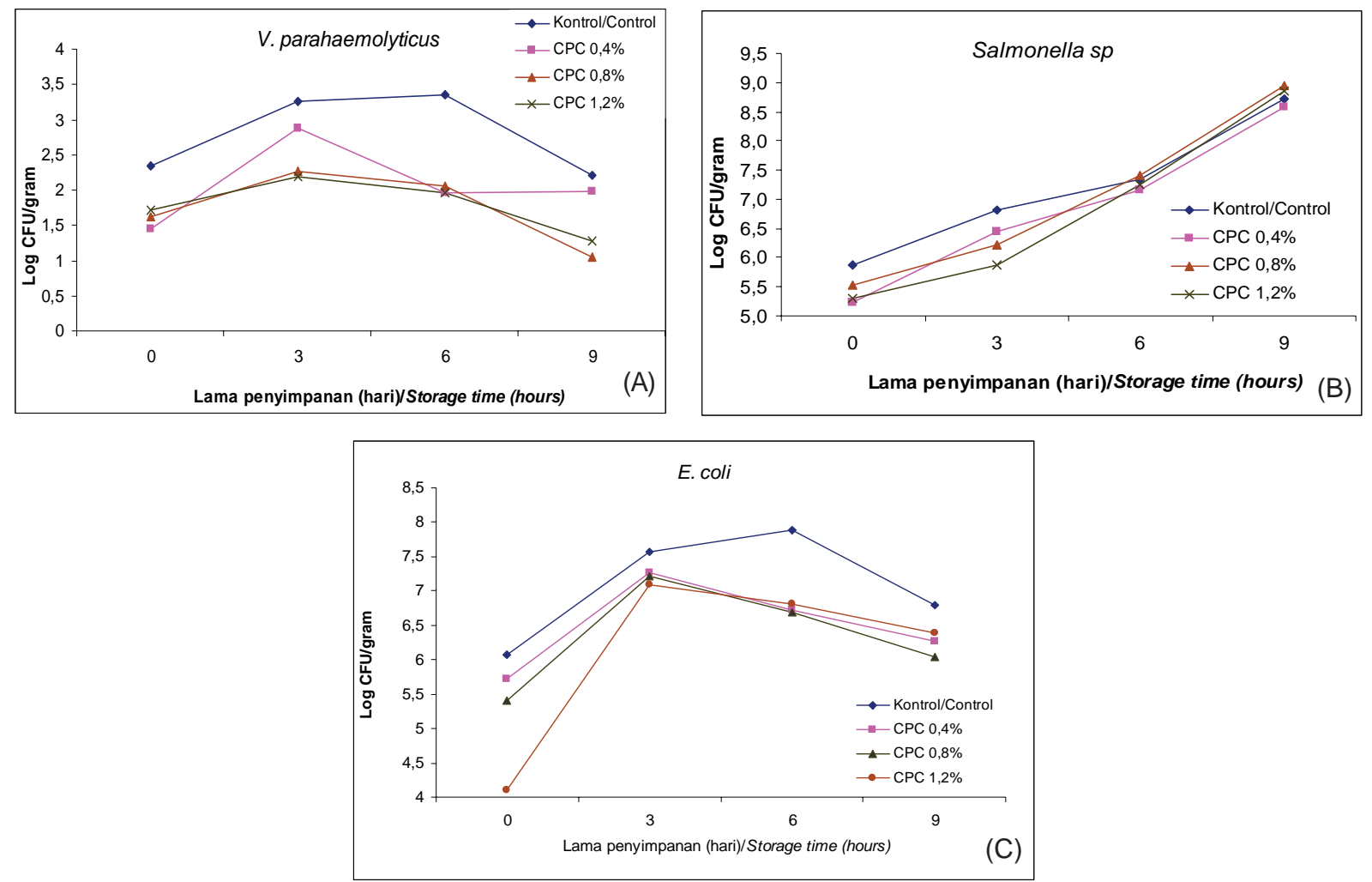

Gambar 3. Kurva pertumbuhan (a) V. parahaemolyticus (b) Salmonella sp. dan (c) E. coli, pada udang yang disimpan di suhu dingin selama 9 hari.

Figure 3. Growth curve of (a) V. parahaemolyticus (b) Salmonella sp. and (c) E. coli, in shrimp stored at cold temperature for 9 days. 
Pertumbuhan bakteri $V$. parahaemolyticus pada udang yang dicelup dengan akuades (kontrol) menunjukkan puncaknya pada hari ke-6 pengamatan. Sedangkan pada kelompok perlakuan, puncak pertumbuhan $V$. parahaemolyticus terjadi pada hari ke-3 yang diikuti dengan fase kematian. Hasil analisis statistik menunjukkan bahwa pada hari ke-0 perlakuan pencelupan CPC memberikan perbedaan yang sangat nyata $(p<0,01)$ dibandingkan kontrol, namun antar perlakuan pencelupan tidak berbeda nyata. Pada hari-hari pengamatan berikutnya, pencelupan CPC 0,8 dan 1,2\% tidak berbeda nyata $(p>0,05)$. Namun kedua perlakuan tersebut berbeda nyata $(p<0,05)$ dibandingkan dengan kontrol dan CPC 0,4\%. Hal ini menunjukkan bahwa CPC 0,4\% tidak efektif menghambat pertumbuhan $V$. parahaemolyticus, sementara perlakuan CPC 0,8 dan 1,2\% memiliki efektifitas yang sama dalam menghambat pertumbuhan bakteri tersebut.

Efektifitas CPC yang lebih tinggi pada suhu dingin dibandingkan dengan suhu kamar menunjukkan adanya efek sinergi antara perlakuan CPC dengan penyimpanan pada suhu dingin. Secara umum pertumbuhan bakteri V. parahaemolyticus pada udang yang disimpan pada suhu dingin selama 9 hari lebih rendah dibandingkan bakteri E. coli dan Salmonella sp. Salah satu faktor yang dapat menyebabkan hal ini adalah adanya tahap pengeblokan udang dengan aquades sehingga pada saat pelelehan, kadar garam pada daging udang menurun terbawa oleh es yang meleleh. Sebagai akibatnya, V. parahaemolyticus tidak tumbuh optimal walaupun bakteri tersebut merupakan bakteri alami pada udang. Bakteri $\mathrm{V}$. parahaemolyticus tumbuh optimal pada kadar garam 2-4\% dan tidak dapat bertahan hidup dalam larutan akuades (FEHD, 2005; WHO, 2011).

Hasil berbeda ditunjukkan oleh bakteri Salmonella sp. yang pertumbuhannya diamati selama 9 hari (Gambar 3b). Secara umum, pencelupan CPC yang disinergikan dengan penyimpanan pada suhu dingin tidak mampu memberikan penghambatan terhadap pertumbuhan Salmonella sp. pada hari ke-6 sampai 9. Hal ini terlihat dari kurva pertumbuhan Salmonella sp. yang memiliki kecenderungan yang sama antara penyimpanan hari ke-6 sampai dengan hari ke-9. Namun demikian pada hari ke-0 dan hari ke-3, perlakuan pencelupan CPC 1,2\% mampu menurunkan jumlah Salmonella sp. sebesar 0,57 dan $0,94 \log c f u / g$ dan berbeda nyata $(p<0,05)$ dibandingkan dengan kontrol.

Penelitian yang dilakukan oleh Thongbai et al. (2006) menunjukkan bahwa perlakuan suhu dingin yang diberikan pada Salmonella sp. tidak dapat menginduksi kerusakan pada membran sel luar dari
Salmonella sp., sehingga CPC tidak dapat merusak membran sel terluar dari bakteri ini. Hal ini berbeda dengan perlakuan pemanasan yang dapat menginduksi perubahan struktur ikatan protein dan lemak yang ada di membran sel.

Pertumbuhan E. coli pada udang yang disimpan pada suhu dingin dapat dilihat pada Gambar 3c. Jumlah E.coli pada udang yang diberi perlakuan pencelupan dalam larutan CPC lebih kecil dan berbeda nyata $(p<0,05)$ jika dibandingkan perlakuan kontrol pada hari ke-0 dan ke-6. Hal ini menunjukkan bahwa perlakuan CPC 0,4; 0,8; dan 1,2\% mampu menghambat pertumbuhan $E$. coli sehingga puncak pertumbuhan terjadi pada hari ke-3, dan hari ke-6 telah terjadi penurunan pertumbuhan. Diduga $E$. coli pada udang yang disimpan pada suhu $4{ }^{\circ} \mathrm{C}$, tanpa adanya perlakuan CPC, masih terus tumbuh sampai dengan hari ke- 6 dan mengalami penurunan setelah hari keenam. Hal ini mengindikasikan adanya efek sinergi pada perlakuan CPC dan suhu penyimpanan terhadap pertumbuhan bakteri E.coli.

\section{KESIMPULAN}

Larutan CPC yang digunakan sebagai bahan pencelup (dipping agent) pada udang efektif untuk menghambat pertumbuhan bakteri $E$. coli dan $V$. parahaemolyticus pada penyimpanan suhu $\pm 4{ }^{\circ} \mathrm{C}$ maupun $\pm 25^{\circ} \mathrm{C}$. Namun demikian, larutan CPC hanya efektif menghambat pertumbuhan bakteri Salmonella $s p$. pada udang yang disimpan di suhu dingin.

Penggunaan larutan CPC 0,8 dan 1,2\% memiliki efektifitas yang sama dalam menghambat pertumbuhan bakteri, sehingga dianjurkan penggunaan larutan yang lebih rendah yaitu 0,8\% CPC agar memenuhi standar yang ditetapkan oleh FDA dan EFSA.

\section{DAFTAR PUSTAKA}

Badan Standardisasi Nasional (BSN). 2006. SNI 012332.3-2006. Cara uji mikrobiologi-Bagian 3: Penentuan Angka Lempeng Total (ALT) pada produk perikanan. Jakarta

Bosilevac, J. M., Arthur, T. M., Wheeler, T. L., Shackelford, S. D., Rossman, M., Reagan, J. O., and Koohmaraie, M. 2004. Prevalence of Escherichia coli O157:H7 and levels of aerobic bacteria and Enterobacteriaceae are reduced when hides are washed and treated with cetylpyridinium chloride at a commercial beef processing plant. J. Food. Prot. 67 (4): 646-650.

Breen, P. J., Salari, H., and Compadre, C. M. 1997. Elimination of Salmonella contamination from poultry tissues by Cetylpyridinium chloride solutions. Journal of Food Protection. 9: 1019-1151. 
Chopra, I. and Roberts, M. 2001. Tetracycline antibiotics: mode of action, applications, molecular biology, and epidemiology of bacterial resistance. Microbiol Mol. Biol. Rev. 65 (2): 232-260.

Commission Regulation (EC) No. 2073/2005 of 25 November 2005 on microbiological criteria for foodstuffs.

Cutter, C.N., Dorsa, W.J., Handie, A., Rodriguez-Morales, S., Zhou, X., Breen, P.J., and Comparde, C.M. 2000. Antimicrobial activity of cetylpyridinium chloride washes againts pathogenic bacteria on beef surface. Journal of Food Protection. 63 (5): 593-600.

Donabeth, J., Rodrigues, T., Shaver, T., and Howart, J. 2013. Novel Quat Test Method for Ensuring Successful Application of Cetylpyridinium Chloride (CPC). Envirotech. 29 July 2013.

Dupard, T. M. 2005. Antimicrobial effect of cetylpyridinium chloride againts Listeria monocytogenes growth on the surface of raw and cooked shrimp. Thesis. Department of Food Science. University of Lousiana.

European Food Safety Authority (EFSA), 2012. Scientific Opinion on the evaluation of the safety and efficacy of Cecure ${ }^{\circledR}$ for the removal of microbial surface contamination of raw poultry products. EFSA Journal, $10(3): 2612$.

Food and Environmental Hygiene Department (FEHD). 2005. Vibrio spesies in seafood. Risk Assessment Studies. Report No. 20. The Government of the Hongkong Special Administrative Region.

IDE-JETRO. 2013. Meeting standards, winning markets. Regional Trade Standard Compliance Report East Asia 2013. UNIDO - IDE JETRO

Kim, J. and Slavik, M.F. 1996. Cetylpyridinium chloride (CPC) treatment on poultry skin to reduce attached Salmonella. Journal of Food Protection. 3: 226-330.

Lim, K. and Mustapha, A. 2004. Effects of cetylpyridinium chloride, acidified sodium chlorite, and potassium sorbate on populations of Escherichia coli O157:H7, Listeria monocytogenes, and Staphylococcus aureus on fresh beef. J. Food Prot. 67(2): 310-315.

Lim, K., and Mustapha, A. 2007. Inhibition of Escherichia coli 0157:H7, Listeria monocytogenes and Staphylococcus aureus on sliced roast beef by cetylpyridinium chloride and acidiûed sodium chlorite. Short communication. Food Microbiology. (24): 89 94.

Maris, P. 1995. Modes of action of desinfectants. Rev. sci. tech. Off. int. Epiz. 14 (1): 47-55.

McDonnell, G. and Russell, A. D. 1999. Antiseptics and Disinfectants: Activity, Action, and Resistance. J. Clin. Microbiol. 12 (1):147-149.

Morales, G., Sierra, P., Mancilla, Paredes, A., Loyola, L. A., Gallardo, O., and Borquez, J. 2003. Secondary metabolites from four medicinal plants from Northern Chile, antimicrobial activity, and biotoxicity against Artemia salina. J. Chile Chem. 48(2).

Ozdemir, G., Yapar, S., and Limoncu, M. H., 2013. Preparation of cetylpyridinium montmorillonite for antibacterial applications. Applied Clay Science. 72: 201-205.

Pohlman, F. W., Stivarius, M. R., McElyea, K. S., Apple, J. K., Johnson, M. G., and Waldroup, A. L. 1999. Reduction of E. coli and Salmonella typhimurium in ground beef utilizing antimicrobial treatments prior to grinding. AAES Research Series. 470: 135-141.

Safe Foods Corporation. 2003. Cecure: Frequently Asked Questions. http://www.safefoods.net/press/files/ Cecure\%20FAQ021804.pdf. Diakses pada tanggal 15 June 2013.

Stopforth, J. D., Samelis, J., Sofos, J. N., Kendall, P. A., and Smith, G. C. 2002. Biofilm formation by acidadapted and Nonadapted Listeria monocytogenes in fresh beef decontamination washings and its subsequent inactivation with sanitizers. J. Food Prot. 65(11): 1717-1727.

Thongbai, B., Gasaluck, P., and Waites, W.M. 2006. Morphological changes of temperature- and $\mathrm{pH}$ stressed Salmonella following exposure to cetylpyridinium chloride and nisin. LWT. 39: 11801188.

Tischer, M., Pradel, G., Ohlsen, K., and Holzgrabe, U. 2012. Quaternary ammonium salts and their antimicrobial potential: targets or nonspecific interactions?. Chem. Med. Chem. 7: $22-31$.

Steel, R. G. D. and Torrie, J. H. 1980. Principles and Procedures of Statistics. Second Edition, New York: McGraw-Hill.

US Food and Drug Administration (US FDA). 2007. Secondary direct food additives permitted in food for human consumption. http://www.cfsan.fda.gov/ /rd/ fr040402. html. Diakses pada tanggal 12 Januari 2013.

US Food and Drug Administration (US FDA). 2011. Fish and Fishery Products Hazard and Controls Guidance. Department of Health and Human Service, Center for Food Safety and Applied Nutrition.

US Food and Drug Administration (US FDA). 2013. Import Refusal Reports. http://www.accessdata.fda.gov/ scripts/importrefusals/ir_months.cfm? LType $=$ C.

University of Arkansas for Medical Sciences. 2004. UAMS Discovery Enhances Safety of World's Food Supply Safe Foods Corporation Receives FDA Approval for Cecure $^{\mathrm{TM}}$. http://www.uams.edu/update/absolutenm/ te mplates/news2003v2. asp?articleid $=1093$ \& zoneid=25. Diakses pada tanggal 5 Juni 2013.

Wang, H., Li, Y., and Slavik, M. F. 2001. Efficacy of cetylpyridinium chloride in immersion treatment for reducing populations of pathogenic bacteria on fresh-cut vegetables. J. Food Prot. 64(12): 20712074.

Wang, L. L., and Johnson, E. A. 1997. Control of Listeria monocytogenes by monoglycerides in foods. J. Food Prot. 60 (2): 131-138.

Wanger, A. 2007. Disk diffusion test and gradient methodologies in Schwalbe, R., Steele-Moore, L., and Goodwin, A.C (eds) Antimicrobial Susceptibility Testing Protocols. CRC Press. 56 p. 
World Health Organization/Food and Agriculture Organization (WHO/FAO). 2011. Risk assessment of
Vibrio parahaemolyticus in seafood. Interpretative summary and technical report. MRA Series 16. 